\title{
Synthesis and transfer of RNAi construct for potential knock-down of gene expression of root-knot nematode (Meloidogyne graminicola) to rice (Oryza sativa L.)
}

\author{
Phong V. Nguyen*, Phuong T. Nguyen, Nhi T. Y. Le, \& Loan T. N. Nguyen \\ Department of Biotechnology, Nong Lam University, Ho Chi Minh City, Vietnam
}

ARTICLE INFO
Research Paper
Received: April 01, 2020
Revised: May 28, 2020
Accepted: July 01, 2020
Keywords
Agrobacterium
Effector
Gene silencing
MicroRNA
Rice root-knot nematode
*Corresponding author
Nguyen Vu Phong
Email: nvphong@hcmuaf.edu.vn

\begin{abstract}
Effectors play key roles in the parasitism of the plant-parasitic nematode. Silencing the effector-coding genes was applied to study the function and role of nematode effectors. In this study, the Mgra16281 gene (ID: MK322955.1) encoding an effector with the unknown function was cloned from the rice root-knot nematode Meloidogyne graminicola isolated in Long An province. To knock-down the expression of this gene, an artificial microRNA was synthesized based on the Osa-MIR528 precursor and inserted into an expression vector. This microRNA can be expressed in rice to investigate the function of MGRA16281 of root-knot nematode via host-induced gene silencing approach (HIGS).
\end{abstract}

Cited as: Nguyen, P. V., Nguyen, P. T., Le, N. T. Y., \& Nguyen, L. T. N. (2020). Synthesis and transfer of RNAi construct for potential knock-down of gene expression of root-knot nematode (Meloidogyne graminicola) to rice (Oryza sativa L.). The Journal of Agriculture and Development 19(4), 36-44. 


\title{
Tổng hợp và chuyển cấu trúc RNAi có khả năng bất hoạt gene tuyến trùng sưng rễ (Meloidogyne graminicola) vào cây lúa (Oryza sativa L.)
}

\author{
Nguyễn Vũ Phong*, Nguyễn Thế Phương, Lê Thị Yến Nhi \& Nguyễn Thị Ngọc Loan \\ Bộ Môn Công Nghệ Sinh Học, Trường Đại Học Nông Lâm TP.HCM, TP. Hồ Chí Minh
}

THÔNG TIN BÀI BÁO
Bài báo khoa học
Ngày nhận: 01/04/2020
Ngày chînh sưa: 28/05/2020
Ngày chấp nhận: 01/07/2020
Từ khóa
Agrobacterium
Câm lặng gene
Effector
MicroRNA
Tuyến trùng sưng rễ lúa
*Tác giả liên hệ
Nguyễn Vũ Phong
Email: nvphong@hcmuaf.edu.vn

\section{1. Đặt Vấn Đề}

Tuyến trùng ký sinh thực vật (plant-parasitic nematode) là sinh vật gây hại trực tiếp lên hầu hết các bộ phận của cây và gián tiếp mở đường tạo điều kiện cho các tác nhân gây hại khác như vi khuẩn, virus xâm nhập vào cây trồng gây hại nặng thêm. Các triệu chứng gây hại do tuyến trùng gây ra khó phân biệt với triệu chứng do các tác nhân phi sinh học như thời tiết bất lợi hay thiếu dinh dưỡng gây ra. Hằng năm, tuyến trùng ký sinh thực vật chịu trách nhiệm cho hơn 80 tỷ USD thiệt hại nông nghiệp trên toàn thế giới (Nicol \& ctv., 2011). Tuyến trùng sưng rễ Meloidogyne là một trong những loài tuyến trùng ký sinh thực vật gây thiệt hại về kinh tế lớn nhất ở vùng ôn đới và nhiệt đới (Trudgill \& Block, 2001). Loài tuyến trùng này có khả năng ký sinh hơn 5.500 loài thực vật, ký chủ ưa thích là rau cải, cây họ đậu, cây lấy sợi, cây ăn quả và cây trồng đồn điền. Riêng cây lúa, sản lượng đã bị giảm từ 10 - 25\% (Gregory \& ctv., 2017). Meloidogyne có trên 60 loài, trong đó 4 loài $M$. javanica, $M$. arenaria, $M$. incognita, $M$. hapla là ký sinh gây hại nghiêm trọng (Eisenback \& Triantaphyllou, 1991). Meloidogyne graminicola - một trong những loài tuyến trùng phổ biến gây hại trên lúa và được xem là đe dọa lớn đối với nền nông nghiệp lúa gạo, đặc biệt ở châu Á (Dutta \& ctv, 2012). Về mặt kinh tế, M. graminicola ước tính gây thiệt hại khoảng 17 - 32\% sản lượng lúa (Kyndt \& ctv., 2014). Ở Việt Nam, loài này ký sinh tương đối phổ biến trên lúa cạn (giai đoạn lúa non, khi chưa ngập nước) tại đồng bằng sông Cửu Long (Gao \& Liu, 2010).

Effector là các protein tuyến trùng tiết vào trong tế bào thực vật, đóng vai trò tác động và thay đổi phản ứng của cây chủ (Hogenhout \& 
ctv., 2009), tạo thuận lợi cho quá trình ký sinh. Thông qua kim chích, effector được chuyển vào tế bào nhằm sửa đổi, ngăn chặn hoặc chống lại phản ứng phòng vệ, từ đó tạo điều kiện xâm nhập hoặc di trú của tuyến trùng trong rễ cây. Ngoài ra, các effector bắt đầu hoặc duy trì sự phát triển của các vị trí dinh dưỡng, hỗ trợ cho sự tăng trưởng và phát triển của tuyến trùng (Goverse \& Smant, 2014). Sử dụng phương pháp làm câm lặng các gene mã hóa các protein độc tính này đang được quan tâm nghiên cứu và hứa hẹn là công cụ hữu hiệu tạo giống cây trồng kháng tuyến trùng sưng rễ.

Nghiên cứu này trình bày kết quả tổng hợp amiRNA (artificial miRNA) có khả năng bất hoạt gene Mgra16281, mã hóa cho một effector chưa biết chức năng, tạo dòng từ mẫu tuyến trùng sưng rễ $M$. graminicola. Cấu trúc amiRNA được chuyển vào cây lúa nhằm bước đầu tìm hiểu vai trò của effector này trong quá trình ký sinh thực vật của tuyến trùng sưng rễ.

\section{Vật Liệu và Phương Pháp Nghiên Cứu}

\subsection{Vật liệu nghiên cưu}

Vector pNW55 chứa Osa-miR528 precursor (AN: MI0003201) được cung cấp bởi Department of Molecular Biology, Max Planck Institute for Developmental Biology, Đức.

Vector pC5300OE được thiết kế bằng cách chèn cassette attP1-ccdB-attP2 GatewayR vào vùng multiple cloning sites của vector pCambia1300intA.Ubi-tnos (còn có tên IRS154) giữa maize ubiquitin promoter/first exon/first intron sequence và trình tự NOS polyadenylation (JC Breitler, chưa công bố) được cung cấp bởi CIRAD Montpellier, Pháp.

Vi khuẩn E. coli TOP10 và Agrobacterium tumefaciens EHA105 từ Bộ môn Công nghệ Sinh học, Trường Đại học Nông Lâm Thành phố Hồ Chí Minh.

\subsection{Thu thập tuyến trùng Meloidogyne graminicola}

Tuyến trùng Meloidogyne được phân lập từ ruộng lúa ở huyện Thạnh Hóa, tỉnh Long An. Nguồn tuyến trùng được lưu giữ trong nhà lưới bằng cách lây nhiễm tất cả âu trùng cảm nhiễm tuổi 2 (J2s) nở từ một bọc trứng lên cây lúa IR64 15 ngày tuổi. Sau 60 ngày, dòng tuyến trùng sưng rễ được nhận diện nhờ đặc điểm vân sinh môn con cái theo Golden \& Birchfield (1965) và SCAR-PCR với primer chuyên biệt tuyến trùng M. graminicola Mg-F (GGG GAA GAC ATT TAA TTG ATG ATC AAC) và Mg-R (GGT ACC GAA ACT TAG GGA AAG) theo Bellafiore \& ctv. (2015). Sản phẩm PCR được giải trình tự và so sánh với trình tự hiện diện trên Genbank.

\subsection{Tạo dòng gene Mgra16281}

RNA tổng số của J2s được tách chiết bởi GeneJET RNA Purification Kit (Thermo Scientific, Mỹ), tiếp đến tổng hợp $\mathrm{cDNA}$ bằng RevertAid First Strand cDNA Synthesis Kit (Thermo Scientific, Mỹ) sử dụng primer oligo dT. Đoạn trình tự mã hóa protein được tổng hợp bằng $\mathrm{PCR}$ với primer Mg16281-F (ATG TTT TTT CTA AAA TAT TTC CCA ATT TCA) và Mg16281-R (TTA ATT CTT CTT TGA AGA CAA ATT ACA $\mathrm{G})$. Chu kỳ nhiệt của phản ứng gồm 35 chu kỳ $94^{\circ} \mathrm{C} / 30$ giây, $50^{\circ} \mathrm{C} / 30$ giây, $72^{\circ} \mathrm{C} / 1$ phút. Sản phẩm $\mathrm{PCR}$ được tinh sạch bằng GenJET Gel Extraction Kit (Thermo Scientific) và nối vào vector pJET1.2/blunt (Thermo Scientific). Sản phẩm nối được biến nạp vào tế bào $E$. coli $\mathrm{TOP} 10$ bằng phương pháp sốc nhiệt (Sambrook \& Russell, 2001). Các khuẩn lạc chứa vector tái tổ hợp được sàng lọc nhờ kháng sinh và $\mathrm{PCR}$ colony. Plasmid tái tổ hợp được tách chiết bằng GeneJET Plasmid Miniprep Kit (Thermo Scientific) và gene tạo dòng được giải trình tự bởi First Base (Malaysia).

\subsection{Thiết kế và tổng hợp miRNA nhân tạo}

Dựa vào trình tự gene Mgra16281 được tạo dòng, các microRNA nhân tạo (amiRNA) có khả năng làm câm lặng biểu hiện gene mục tiêu được thiết kế nhờ công cụ Designer của trang web WMD3 (http://wmd3.weigelworld.org). Từ danh sách các miRNA nhân tạo gợi ý được đưa ra bởi WMD3, kiểm tra và lựa chọn 01 amiRNA theo tiêu chí được đề xuất bởi Schwab \& ctv. (2006) gồm (1) bất hoạt gene mục tiêu ở tuyến trùng mà không bất hoạt các gene của cây lúa (bao gồm hai nhóm indica và japonica) nhờ công cụ Target Search của WMD3 trên hai database Oryza sativa Indica Group PUT v183 (PGDP) và Oryza sativa Japonica Group PUT v183 (PGDP); (2) vị trí gắn của miRNA nhân tạo với mRNA mục tiêu nằm ở vùng 3 ; (3) năng lượng liên kết giữa 
Bảng 1. Các primer sử dụng tổng hợp các microRNA nhân tạo bằng $\mathrm{PCR}$ overlapping

\begin{tabular}{ll}
\hline Primer & Trình tự $\left(5^{\prime} \rightarrow 3^{\prime}\right)$ \\
\hline I miR & agTTTCGTTTCAGAACGGAACGAcaggagattcagtttga \\
II miR & tgTCGTTCCGTTCTGAAACGAAActgctgctgctacagcc \\
III miR*s & ctTCGTTGCGTACTGAAACGAAAttcctgctgctaggctg \\
IV miR*a & aaTTTCGTTTCAGTACGCAACGAagagaggcaaaagtgaa \\
\hline
\end{tabular}

amiRNA với mRNA mục tiêu từ -35 đến -40 $\mathrm{kcal} / \mathrm{mol}$, không cao quá $-30 \mathrm{kcal} / \mathrm{mol}$; (4) không bắt cặp sai từ vị trí 2-12 của amiRNA đối với đoạn mục tiêu. Công cụ Oligo của WMD3 được sử dụng thiết kế các primer để thay thế đoạn 21 nu của precursor Osa-MIR528 bởi đoạn miRNA 21 nu mới nhờ kỹ thuật PCR overlapping theo Warthmann \& ctv. (2008) (Bảng 1).

Cấu trúc amiRNA mới được nhân dòng bởi hệ thống vector pJET1.2/blunt (Thermo Scientific, Mỹ). Trình tự microRNA nhân tạo được kiểm tra nhằm đảm bảo tính chính xác trước khi gắn vào vector biểu hiện pC5300OE.

\subsection{Gắn cấu trúc amiRNA vào vector biểu hiện}

Đoạn MIR528 trong plasmid pC5300OE được thay thế bằng đoạn trình tự amiRNA tổng hợp. Plasmid pC5300OE và đoạn amiRNA được xử lý bằng enzyme cắt BamHI và PstI (Thermo Scientific) và nối với nhau nhờ T4 DNA ligase (Thermo Scientific) để tạo plasmid tái tổ hợp. Plasmid tái tổ hợp pC5300OE-amiRNA được biến nạp vào trong tế bào $E$. coli TOP10 khả biến bằng phương pháp sốc nhiệt. Trình tự và hướng chèn của amiRNA trong vector pC5300OE được kiểm tra trước khi biến nạp plasmid tái tổ hợp vào vi khuẩn Agrobacterium tumefaciens EHA105 để chuyển cấu trúc amiRNA vào cây chủ.

\subsection{Tạo cây lúa mang cấu trúc miRNA nhờ vi khuẩn Agrobacterium tumefaciens}

Giống lúa IR64 được sử dụng chuyển gene theo quy trình của Sahoo \& ctv. (2011) với một số biến đổi. Hạt lúa chín được bóc vỏ trấu không làm tổn thương đến phôi hạt. Tiếp theo hạt được khử trùng bằng khí chlorine trong 2 giờ, ngâm trong cồn $70^{\circ}$ trong 1 phút và nước javel $15 \%$ trong 20 phút, sau đó được rửa sạch bằng nước cất tiệt trùng. Hạt được thấm khồ và đặt vào môi trường cảm ứng tạo mô sẹo (MCI, môi trường khoáng MS cơ bản chứa tất cả các vitamin bổ sung $30 \mathrm{~g} / \mathrm{L}$ maltose, casein hydrolysate $0,3 \mathrm{~g} / \mathrm{L}, 0,6 \mathrm{~g} / \mathrm{L} \mathrm{L-}$ proline, 3,0 mg/L 2,4-dichlorophenoxyacetic acid (2,4-D), 0,25 mg/L 6-benzylaminopurine (BAP), điều chỉnh $\mathrm{pH}$ đến 5,8 trước khi hấp khử trùng). Mẫu đặt trong tối ở nhiệt độ $27^{\circ} \mathrm{C} \pm 1^{\circ} \mathrm{C}$ trong 3 tuần.

Khuẩn lạc A. tumefaciens EHA105 được tăng sinh trong $5 \mathrm{~mL}$ môi trường YEP lỏng bổ sung $10 \mathrm{mg} / \mathrm{L}$ rifampicin, $50 \mathrm{mg} / \mathrm{L}$ kanamycin. Dịch khuẩn được ủ ở nhiệt độ $28^{\circ} \mathrm{C}$, lắc 200 vòng/phút trong 16 giờ. Sau đó chuyển $400 \mu \mathrm{L}$ dịch khuẩn sang $100 \mathrm{~mL}$ môi trường YEP bổ sung kháng sinh và nuôi cấy với điều kiện tương tự. $\mathrm{Khi} \mathrm{OD}_{600}$ đạt 1,0 sinh khối vi khuẩn được thu nhận bởi ly tâm 3.200 vòng/phút trong 15 phút ở $4^{\circ} \mathrm{C}$ và được pha loãng trong môi trường MCI chứa $150 \mu \mathrm{M}$ acetosyringone.

Mô sẹo phôi hóa được lây nhiễm với dịch khuẩn $\mathrm{OD}_{600}$ từ 0,1 - 0,3 trong 10,20,30 phút kêt hợp lắc 50 vòng/phút và làm khô với giấy thấm vô trùng trong 5 phút. Sau đó, mô sẹo được đặt trên môi trường đồng nuôi cấy (MCI chứa $10 \mathrm{~g} / \mathrm{L}$ glucose; $\mathrm{pH} 5,2 ; 150 \mu \mathrm{M}$ acetosyringone) và ủ ở $27^{\circ} \mathrm{C}$ $\pm 1^{\circ} \mathrm{C}$ trong tối. Sau 48 giờ đồng nuôi cấy, mô sẹo được ngâm và rửa với cefotaxime $250 \mathrm{mg} / \mathrm{L}$ nhiều lần, thấm khô với giấy thấm vô trùng. Tiếp theo, mẫu được đặt trên môi trường chọn lọc (MSM, MCI bổ sung $250 \mathrm{mg} / \mathrm{L}$ cefotaxime và $50 \mathrm{mg} / \mathrm{L}$ hygromycin) nuôi ở $27 \pm 1^{\circ} \mathrm{C}$ trong tối 12 ngày. Sau lần chọn lọc đầu tiên, chỉ những mô sẹo chắc sáng được chuyển sang môi trường MSM cho lần chọn lọc thứ hai và ủ ở $27 \pm 1^{\circ} \mathrm{C}$ trong tối 10 ngày. Tiếp đến, mô sẹo tiếp tục được chuyển sang môi trường MSM cho lần chọn lọc thứ ba ở $27 \pm 1^{\circ} \mathrm{C}$ trong tối 5 ngày. Sau 3 lần chọn lọc, những mô sẹo phôi hóa được chuyển sang môi trường tiền tái sinh MSRMa (MS bổ sung $30 \mathrm{~g} / \mathrm{L}$ maltose, 2 $\mathrm{mg} / \mathrm{L}$ kinetin, $0,2 \mathrm{mg} / \mathrm{L}$ naphthalene acetic acid (NAA), $\mathrm{pH} 5,8 ; 250 \mathrm{mg} / \mathrm{L}$ cefotaxime và $30 \mathrm{mg} / \mathrm{L}$ hygromycin) ở $27 \pm 1^{\circ} \mathrm{C}$ trong tối 7 ngày. Sau đó, chuyển mẫu sang môi trường MSRMb (MS, 30 $\mathrm{g} / \mathrm{L}$ maltose, 2,7 mg/L BAP, 1,2 mg/L kinetin, $0,5 \mathrm{mg} / \mathrm{L}$ NAA, pH 5,$8 ; 250 \mathrm{mg} / \mathrm{L}$ cefotaxime 
và $30 \mathrm{mg} / \mathrm{L}$ hygromycin) nuôi ở điều kiện sáng (4.000 lux) trong 4 ngày để tiếp tục tái sinh.

Để tạo rễ, chồi được chuyển sang môi trường tạo rễ MROM (1/2 MS, $30 \mathrm{~g} / \mathrm{L}$ sucrose, $3,0 \mathrm{~g} / \mathrm{L}$ phytagel, $\mathrm{pH} 5,8 ; 250 \mathrm{mg} / \mathrm{L}$ cefotaxime và 30 $\mathrm{mg} / \mathrm{L}$ hygromycin) và duy trì ở $27 \pm 1^{\circ} \mathrm{C}$ ở điều kiện sáng như trên trong 1 tuần. Cây lúa sau khi được tạo rễ hoàn chỉnh sẽ chuyển trồng trong nhà lưới.

\subsection{Kiểm tra sự hiện diện của gen chuyển}

Dựa vào sự hiện diện của gene hptII kháng hygromycin trong đoạn T-DNA, DNA tổng số của mẫu chồi giả định chuyển gene được ly trích bằng GeneJET Plant Genomic DNA Purification Kit và thực hiện phản ứng $\mathrm{PCR}$ với cặp primer chuyên biệt hptII-F (5'-AGC TGC GCC GAT GGT TTC TAC AA-3') và hptII-R (5'-ATC GCC TCG CTC CAG TCA ATG-3'). Chu trình nhiệt của phản ứng $\mathrm{PCR}$ là $94^{\circ} \mathrm{C} / 5$ phút, $35 \mathrm{chu}$ kỳ $\left(94^{\circ} \mathrm{C} / 30\right.$ giây, $64^{\circ} \mathrm{C} / 30$ giây, $72^{\circ} \mathrm{C} / 60$ giây), $72^{\circ} \mathrm{C} / 10$ phút. Kiểm tra kết quả $\mathrm{PCR}$ bằng điện di trên gel agarose $1 \%, 80 \mathrm{~V}$, trong 30 phút.

\section{Kết Quả và Thảo Luận}

\subsection{Thu thập tuyến trùng Meloidogyne graminicola}

Từ mẫu rễ lúa thu thập đã phân lập dòng tuyến trùng sưng rễ ký sinh. Để định danh tuyến trùng, hình dạng vân sinh môn của năm con cái trưởng thành từ dòng tuyến trùng được quan sát ghi nhận. Vân sinh môn có hình bầu dục, không có đường bên, có sự hội tụ của các đường cong ở lớp biểu bì và hội tụ tại đường vân cuối cùng. Đối chiếu với mô tả của Golden \& Birchfield (1965) có thể xác định dòng tuyến trùng phân lập là tuyến trùng $M$. graminicola (Hình 1A). Để củng cố kêt quả định danh bằng hình thái, SCAR-PCR với primer chuyên biệt loài $M$. graminicola đã được áp dụng theo Bellafiore \& ctv. (2015). Kết quả điện di cho thấy đã khuếch đại một đoạn DNA duy nhất kích thước tương đương 640 bp từ DNA tổng số của con cái (Hình 1B).

Kết quả BLAST cho thấy trình tự sản phẩm tương đồng từ 99 - 100\% với sản phẩm của $M$. graminicola phân lập từ Việt Nam và Trung Quốc. Từ kết quả định danh hình thái và phân tử, dòng tuyến trùng sưng rễ lúa phân lập từ Long An được xác định là tuyến trùng Meloidogyne graminicola.

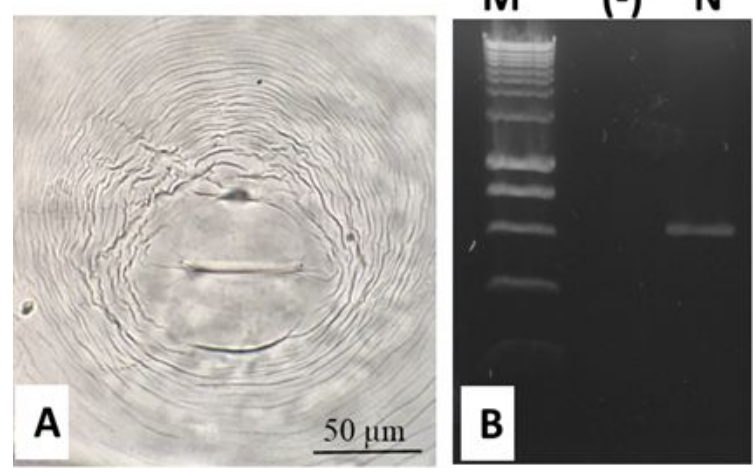

Hình 1. Vân sinh môn con cái $(\mathrm{A})$ và sản phẩm $\mathrm{Mg}$ SCAR-PCR (B) tuyến trùng.

(M) DNA ladder 1 kb; (-) Đối chứng âm; (N) Tuyến trùng.

\subsection{Tạo dòng gene Mgra16281}

Từ cDNA tổng số của dòng tuyến trùng phân lập đã khuếch đại được sản phẩm có kích thước lớn hơn $400 \mathrm{bp}$ tương ứng với kích thước gene mục tiêu (420bp) (Hình 2).

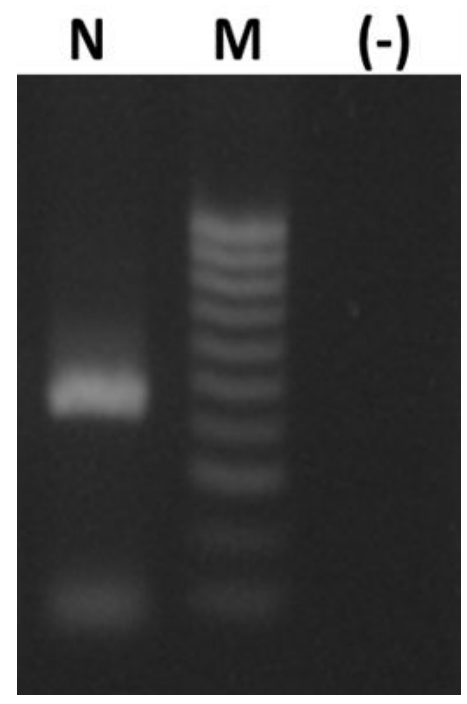

Hình 2. Kết quả điện di sản phẩm RT-PCR khuếch đại đoạn mã hóa gene.

(M) DNA marker 100 bp; (-) Đối chứng âm; (N) Tuyến trùng.

Kết quả tạo dòng gene trong vi khuẩn $E$. coli TOP10 sử dụng vector pJET1.2/blunt cũng cho thấy đã tạo được vector tái tổ hợp mang đoạn gene mục tiêu. Trình tự đoạn gene khuếch đại được hiệu chỉnh và tương đồng $97 \%$ với trình tự gene Mgra16281 trong dữ liệu bộ gene của 

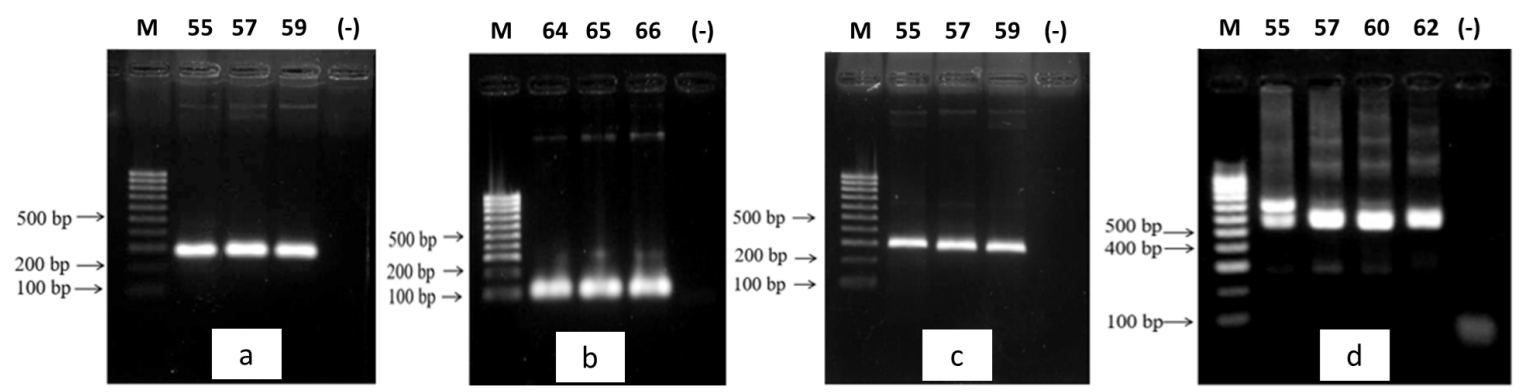

Hình 3. Kết quả điện di sản phẩm PCR tổng hợp miR16281-111.

(M): DNA marker 100 bp; (-) Đối chứng âm; (a, b, c, d): Các phản ứng PCR thành phần.

M. graminicola (Somvanshi \& ctv., 2018) và $80 \%$ với Minc16281 của M. incognita (MH315945.10). Trình tự đoạn gene Mgra16281 của dòng tuyến trùng M. graminicola được đăng ký trên Genbank (MK322955.1) và sử dụng làm khuôn để thiết kế các miRNA nhân tạo.

\subsection{Thiết kế và tổng hợp miRNA nhân tạo}

Trình tự đoạn gene Mgra16281 của dòng tuyến trùng $M$. graminicola được sử dụng để thiết kế các miRNA nhân tạo nhờ phần mềm WMD3. Sau khi tối ưu nhiệt độ bắt cặp và thời gian kéo dài của từng phản ứng thành phần $(\mathrm{a}, \mathrm{b}, \mathrm{c})$ đã thu được được sản phẩm có kích thước lần lượt khoảng $257 \mathrm{bp}, 87 \mathrm{bp}, 259 \mathrm{bp}$. Các sản phẩm này dùng làm khuôn cho $\mathrm{PCR}$ overlapping (d) tổng hợp đoạn precursor mang đoạn amiRNA kích thước khoảng 554 bp đúng bằng kích thước lý thuyết mong đợi (Hình 3).

Cấu trúc precursor mang miR16281-111 được nhân dòng nhờ vector pJET1.2/blunt trong tế bào $E$. coli TOP10 và sàng lọc dòng vi khuẩn mang vector tái tổ hợp bằng $\mathrm{PCR}$ colony. Kết quả điện di cho băng DNA sáng, rõ và đúng kích thước dự kiến vào khoảng 672 bp. Plasmid tái tổ hợp của 3 dòng vi khuẩn được tách chiết và gửi giải trình tự hai chiều. Kết quả sau hiệu đính cho thấy cấu trúc amiR16281-111 có chiều dài 549 nu và trình tự đúng với dự tính (Hình 4).

\subsection{Gắn cấu trúc amiRNA vào vector biểu hiện tạo vector chuyển gene}

Vector pC5300OE được sử dụng làm vector biểu hiện cấu trúc amiRNA trong cây lúa. Hai cấu trúc pC5300OE và pJET2.1-miR16281-111 được xử lý bằng enzyme cắt $P s t \mathrm{I}$ và $B a m \mathrm{HI}$. Plasmid
pC5300OE sau khi được cắt tạo sản phẩm có gồm hai phân đoạn kích thước khoảng 400 bp và 10 kb (Hình 5A). pJET2.1-miR16281-111 sau khi cắt thu được ba băng có kích thước khoảng 250 bp, $500 \mathrm{bp}$ và $2 \mathrm{~kb}$ (Hình $5 \mathrm{~B}$ ).

Sản phẩm bao gồm pC5300OE mở vòng và amiR16281-111 được thu hồi từ gel nối bằng enzyme T4 ligase tạo plasmid tái tổ hợp. Plasmid pC5300OE-16281-111 tiếp tục được nhân dòng trong hệ thống tế bào $E$. coli TOP10 và biến nạp vào vi khuẩn $A$. tumefaciens EHA 105 Việc sàng lọc tế bào mang vector tái tổ hợp được thực hiện nhờ phản ứng PCR với cặp primer IV (miRNA reverse) và I (miRNA* forward) xác định sự hiện diện của miR16281-111. Kết quả PCR 7 khuẩn lạc tạo băng sáng rõ, kích thước tương đương 87 bp chứng tỏ amiR16281-111 đã được nối thành công vào vector pC5300 (Hình 6).

\subsection{Tạo cây lúa mang cấu trúc miRNA}

Mô sẹo 18 ngày tuổi có màu trắng ngà (Hình 7a) được lây nhiễm với dịch vi khuẩn $A$. tumefaciens, sau đó cấy lên môi trường đồng nuôi cấy, ủ trong tối ở $28^{\circ} \mathrm{C}$. Các mô sẹo hóa nâu sau 5 ngày nuôi trên môi trường chọn lọc lần I (Hình 7b) có thể mô sẹo chưa có biểu hiện tính kháng kháng sinh hoặc do lớp tế bào bề mặt của mô sẹo không tiếp xúc với môi trường nuôi cấy nên hóa nâu và chết. Sau 10 ngày xuất hiện các khối mô sẹo trắng ngà phát triển từ các mẫu mô hóa nâu (Hình 7c). Sau 12 ngày mô sẹo được cấy chuyền sang môi trường chọn lọc lần II trong 10 ngày và môi trường chọn lọc lần III trong 7 ngày. Không có hiện tượng tái nhiễm vi khuẩn sau giai đoạn đồng nuôi cấy, mô sẹo sống sót tăng sinh chậm. Mô sẹo được cấy sang môi trường tạo chồi, để trong tối 7 ngày, sau đó chuyển ra ánh sáng. Sau 


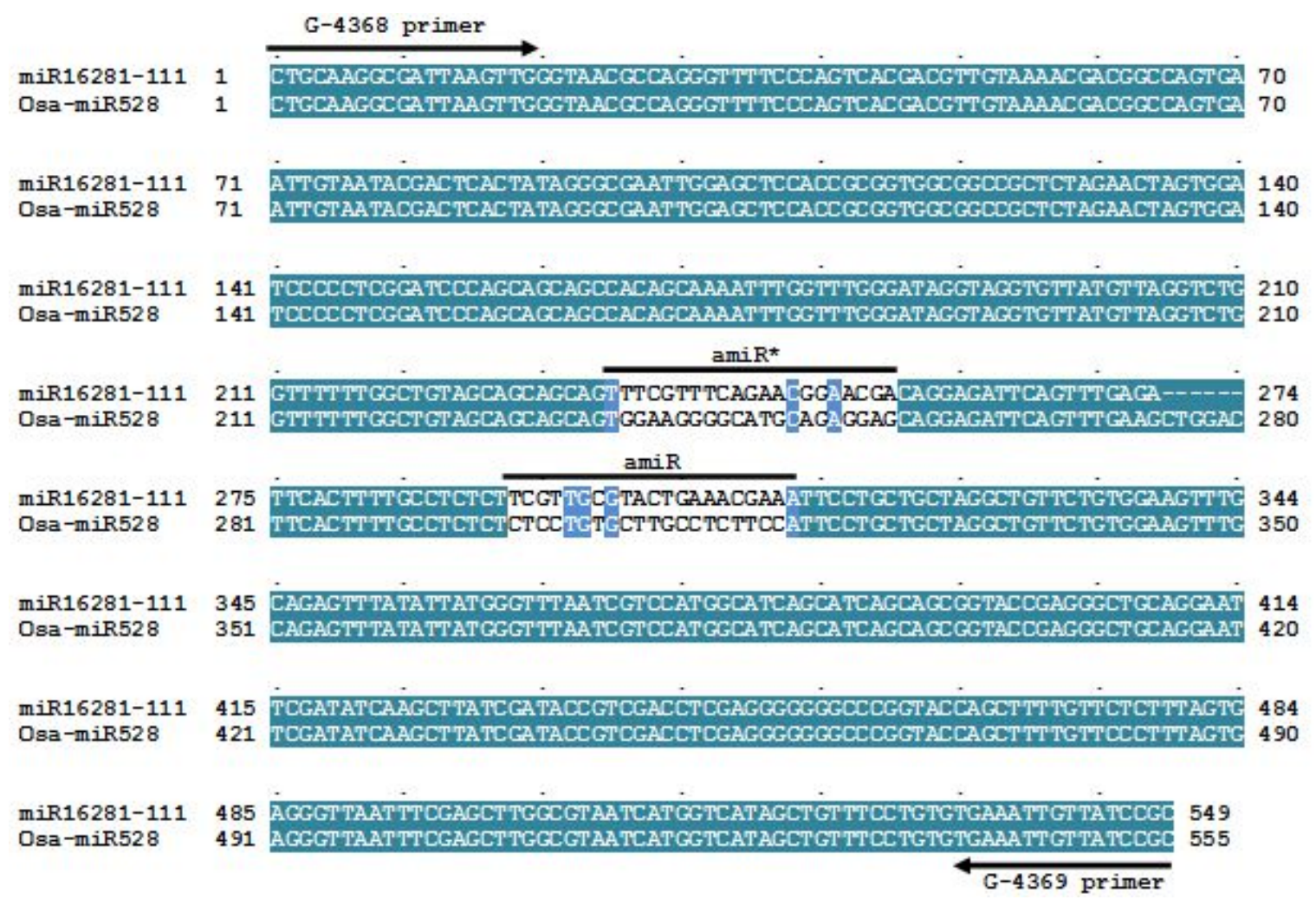

Hình 4. Trình tự 21 nu amiR16281-111 thay thế vào trình tự 21 nu của precursor Osa-miR528.
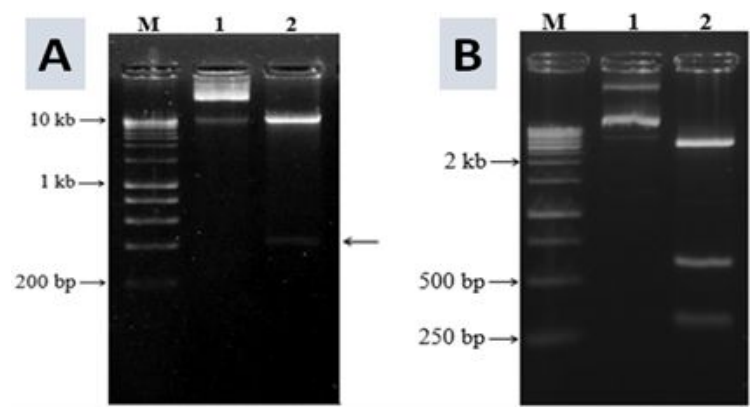

Hình 5. Kết quả điện di sản phẩm cắt pC5300OE (A) và $\mathrm{pJET} 2.1-\mathrm{miR} 16281-111(\mathrm{~B})$.

(M) DNA ladder 1 kb; (1) Không enzyme; (2) BamHI và $P s t \mathrm{I}$.

7 ngày một số mô sẹo hình thành chồi (Hình 7 de). Sau 15 ngày, các chồi phát triển tốt được tách chuyển sang môi trường tạo rễ và cây được trồng trong nhà lưới để thu hạt.

DNA của 5 chồi giả định chuyển gene được tách chiết và tiến hành phản ứng PCR phát hiện sự hiện diện của gene hptII. Kết quả điện di sản phẩm PCR từ DNA 5 chồi giả định chuyển gene

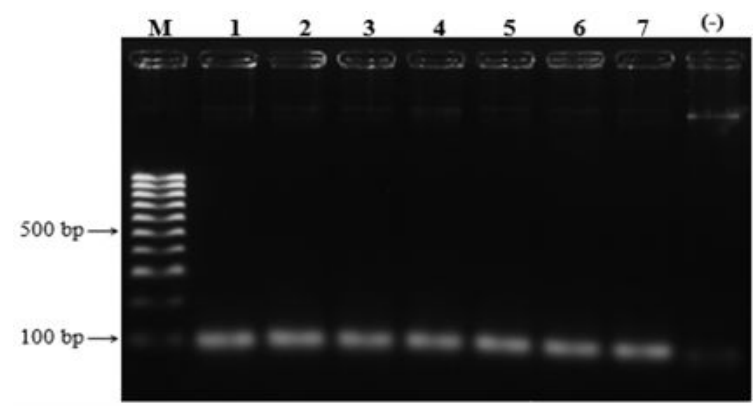

Hình 6. Kết quả điện di sản phẩm PCR sàng lọc dòng vi khuẩn mang vector tái tổ hợp.

(M): DNA ladder 100 bp; (-) Đối chứng âm; (1-7): Các khuẩn lạc.

xuất hiện băng DNA có kích thước khoảng 500 bp, tương ứng với kích thước đoạn gene hptII dự kiến được khuếch đại là 508 bp ở 3 chồi chuyển gene (Hình 8). Do đó, bước đầu đã thu nhận được chồi chuyển gene thế hệ T0. Các chồi được tiếp tục nuôi tạo rễ hoàn chỉnh và trồng ở nhà lưới nhằm thu nhận hạt phục vụ cho các phân tích tiếp theo trên cây T1. 

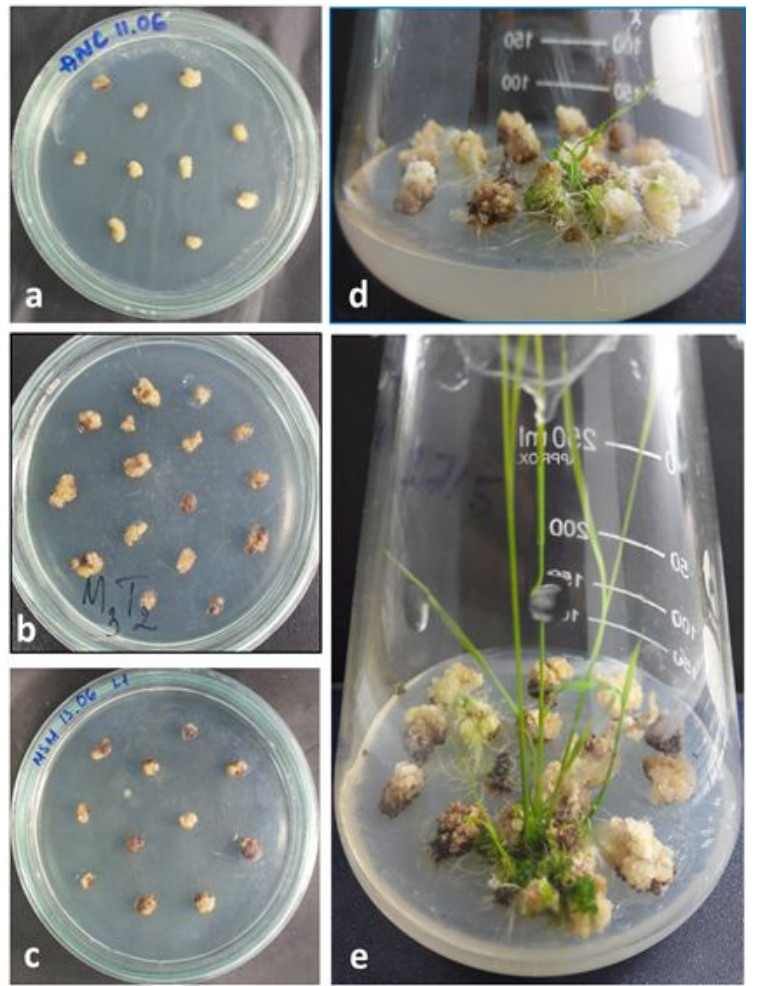

Hình 7. Tạo cây lúa mang cấu trúc amiR nhờ vi khuẩn Agrobacterium tumefaciens.

(a) Mô sẹo phôi hóa được lây nhiễm vi khuẩn; $(b, c)$ Mô sẹo trên môi trường chọn lọc sau 5 ngày và 10 ngày; (d, e) Chồi tạo thành sau 40 và 50 ngày.

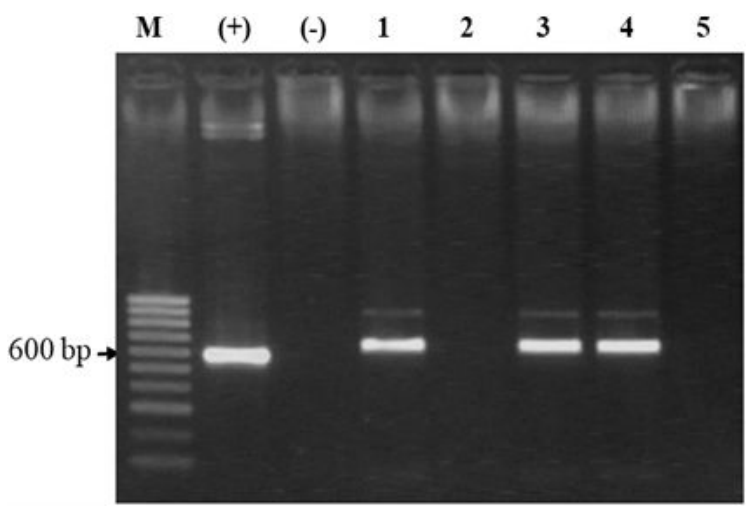

Hình 8. Sự hiện diện của gene hptII trong chồi giả định chuyển gene.

(1) DNA ladder 100 bp; (+) Đối chứng dương; (-) Đối chứng âm; (1-5) DNA chồi giả định chuyển gene.

Mgra16281 là gene mã hóa một effector chưa biết chức năng của tuyến trùng Meloidogyne graminicola. Effector này chứa một đoạn peptide tín hiệu (signal peptide) ở đầu N-terminal và dự đoán có khả năng định vị bên trong tế bào chất của tế bào chủ. Các kết quả thực nghiệm cho thấy khi xử lý tuyến trùng với siRNA chuyên biệt cho mRNA bằng phương pháp soaking đã làm giảm khả năng ký sinh của tuyến trùng. Trong nghiên cứu này, trình tự gene Mgra16281 của dòng tuyến trùng $M$. graminicola ký sinh lúa đã được xác định tương đồng $97 \%$ so với trình tự của M. graminicola từ Ấn Độ (Somvanshi \& ctv., 2018) và $80 \%$ so với $M$. incognita phân lập từ cây đậu nành ở Việt Nam (Nguyen \& ctv., 2019). Điều này làm rõ thêm nhận định về mức độ đa hình của các effector trong cùng một loài và liên loài Meloidogyne sp. (Bellafiore \& Briggs, 2010). Để tìm hiểu chức năng liên quan đến độc tính của effector này ở tuyến trùng, cấu trúc miRNA nhân tạo đã được tổng hợp và chuyển vào trong cây lúa IR64 nhằm giảm mức độ biểu hiện của effector thông qua cây ký chủ (HIGS). Sự biểu hiện của miRNA trong cây lúa và thử nghiệm đánh giá mức độ giảm khả năng ký sinh của tuyến trùng trên cây lúa sẽ được tiếp tục thực hiện để làm sáng tỏ vai trò của effector cung cấp thêm dữ liệu cho lựa chọn phương thức chọn tạo giống và kiểm soát tuyến trùng sưng rễ ở cây trồng.

\section{Kết Luận}

Trình tự gene Mgra16281 mã hóa một effector chưa biết chức năng của tuyến trùng Meloidogyne graminicola đã được xác định trình tự. Dựa vào trình tự của đoạn gene này đã thiết kế và tổng hợp cấu trúc amiRNA có khả năng bất hoạt sự biểu hiện của gene 16281 của tuyến trùng sưng rễ. Cấu trúc này đã được chuyển vào cây lúa nhờ vào vi khuẩn $A$. tumefaciens EHA105 nhằm nghiên cứu vai trò của effector 16281 trong quá trình ký sinh cây lúa của tuyến trùng $M$. graminicola.

\section{Lời Cảm Ơn}

Nghiên cứu này được tài trợ bởi Quỹ Phát triển khoa học và công nghệ Quốc gia (NAFOSTED) trong đề tài mã số 106-NN.03-2015.86.

\section{Tài Liệu Tham Khảo (References)}

Bellafiore, S., \& Briggs, S. P. (2010). Nematode effectors and plant responses to infection. Current Opinion in Plant Biology 13(4), 442-448.

Bellafiore, S., Jougla, C., Chapuis, É., Besnard, G., Suong, M., Nguyen, V. P., De Waele, D., Gantet, P., \& Ngo, T. X. (2015). Intraspecific variability of the facultative meiotic parthenogenetic root-knot nematode 
(Meloidogyne graminicola) from rice fields in Vietnam. Comptes Rendus Biologies 338(7), 471-483.

Dutta, T. K., Ganguly, A. K., \& Gaur, H. S. (2012). Global status of rice root-knot nematode, Meloidogyne graminicola. African Journal of Microbiology Research 6(31), 6016-6021.

Eisenback, J. D., \& Triantaphyllou, H. H. (1991) Rootknot Nematodes: Meloidogyne species and races. In W. R. Nickle (Ed). Manual of agricultural nematology (191-274). New York, USA: Marcel Dekker.

Gao, L., \& Liu, X. Z. (2010). Sporulation of several biocontrol fungi as affected by carbon and nitrogen sources in a two-stage cultivation system. The Journal of Microbiology 48(6), 767-770.

Golden, A. M., \& Birchfield, W. (1965). Meloidogyne graminicola (Heteroderidae), a new species of root-knot nematode from grass. Proceedings of the Helminthological Society of Washington 32(2), 228231.

Goverse, A., \& Smant, G. (2014). The activation and suppression of plant innate immunity by parasitic nematodes. Annual Review of Phytopathology 52, 243-265.

Gregory, C. B., Marceline, E., \& Conrad, B. (2017). The impact of plant-parasitic nematodes on agriculture and methods of control. In: Shah, M. M. (Ed.). Nematology: Concepts, diagnosis and control (121-151). London, UK: IntechOpen.

Hogenhout, S. A., Van der Hoorn, R. A., Terauchi, R., \& Kamuon, S. (2009). Emerging concepts in effetor biology of plant-associated organisms. Molecular Plant Microbe Interaction 22, 115-122.

Kyndt, T., Fernandez, D., \& Gheyse, G. (2014). Plantparasitic nematode infections in rice: Molecular and cellular insights. Annual Review of Phytopathology 52(1), 135-153.
Nicol, J. M., Turner, S. J., Coyne, D. L., den Nijs, L., Hockland, S., \& Tahna Maafi, Z. (2011). Current nematode threats to world agriculture. In: Jones, J. T., Gheysen, G., and Fenoll, C. (Eds.). Genomic and molecular genetic of plant nematode interactions (2143). London, UK: Springer.

Nguyen, P. V., Nguyen, L. T. N., Tran, T. B., \& Ton, L. B. (2019). Construction of artificial microRNA expression vectors for inhibition of Minc16281 gene in root-knot nematode Meloidogyne incognita. The Journal of Agriculture and Development 18(4), 62-69.

Sahoo, K. K., Tripathi, A. K., Pareek, A., Sopory, K. S., \& Singla-Pareek, S. L. (2011). An improved protocol for efficient transformation and regeneration of diverse indica rice cultivars. Plant Methods 7(1), 49.

Sambrook, J., \& Russell, D.W. (2001). Molecular cloning: a laboratory manual (Vol. 2, $3^{\text {rd }}$ ed.). New York, USA: Cold Spring Harbor Laboratory Press.

Schwab, R., Ossowski, S., Riester, M., Warthmann, N., \& Weigel, D. (2006). Highly specific gene silencing by artificial miRNAs in Arabidopsis. Plant Cell 18(5), 11211133.

Somvanshi, V. S., Tathode, M., Shukla, R. N., \& Rao, U. (2018). Nematode genome announcement: A draft genome for rice root-knot nematode, Meloidogyne graminicola. Journal of Nematology 50(2), 111-116.

Trudgill, D. L., \& Block, V. C. (2001). Apomictic, polyphagous root- knoot nematodes: exceptionally successful and damaging biotrophic root pathogens. Annual Review of Phytopathology 39(1), 53-77.

Warthmann, N., Chen, H., Ossowski, S., Weigel, D., \& Hervé, P. (2008). Highly specific gene silencing by artificial miRNAs in rice. PLoS ONE 3(3), e1829. 